\title{
Chromosome $3 p$ loss of heterozygosity and mutation analysis of the FHIT and $\beta$-cat genes in squamous cell carcinoma of the head and neck
} María Victoria González, Marta F Pello, Pilar Ablanedo, Carlos Suárez, Victoria Alvarez,
Eliecer Coto
Hospital Central de Asturias, Oviedo, Spain

Laboratorio de Genética Molecular M V González V Alvarez

E Coto

Servicio de Otorrinolaringología M F Pello

C Suárez

Servicio de Patología P Ablanedo

Correspondence to: Dr Eliecer Coto, Servicio de Inmunología, Hospital Central de Asturias, 33006 Oviedo, Spain.

Accepted for publication 30 March 1998

\begin{abstract}
Aims-To study the loss of heterozygosity at the short arm of chromosome 3 in primary tumours from patients with squamous cell carcinoma of the head and neck; to determine whether the FHIT gene, mapped to $3 \mathrm{p} 14.2$ and the CTNNB1 ( $\beta$-cat) gene, mapped to 3 p21, are deleted or mutated in these tumours.

Methods-DNA was extracted from fresh tumours. Loss of heterozygosity was assessed by microsatellite analysis of the following markers: D3S1283 and D3S1286 (3p24), D3S966 (3p21), and D3S1300 (3P14.2). Homozygous deletion was determined by radioactive multiplex polymerase chain reaction of exons 5 and 6 of the FHIT gene. The presence of mutations in FHIT exon 5 and $\beta$-cat exon 3 was studied by single strand conformation polymorphism.

Results-50\% of informative cases (25/50) showed loss of heterozygosity for at least one of the 3p markers. 3p21 was the region with the highest rate of allelic deletion $(63 \%)$. No point mutation was found in FHIT exon 5 or $\beta$-cat exon 3. No case showed homozygous deletion for the FHIT (exons 5 and 6) or the $\beta$-cat exon 3.

Conclusions-The short arm of chromosome 3 is often deleted in the head and neck squamous cell carcinomas. In the remaining alleles of the FHIT or $\beta$-cat genes, no evidence was found for point mutations or deletions, documented in other common carcinomas. Inactivation could occur by different mechanisms such as methylation, or other genes (not studied here) could be target of allelic losses in squamous cell carcinoma of the head and neck.

(f Clin Pathol 1998;51:520-524)
\end{abstract}

Keywords: squamous cell carcinoma of head and neck; loss of heterozygosity; mutation analysis; FHIT gene; $\beta$-cat gene

Head and neck squamous cell carcinoma (HNSCC) is one of the most common types of cancer in the world. In Western countries it accounts for up to $5 \%$ of all cancers. ${ }^{12}$ Despite efforts to improve early diagnosis and treatment of patients with these neoplasms, their prognosis remains poor. Its five year survival rate has not changed in recent years, and is still one of the lowest among the prevalent cancers.
HNSCC is strongly associated with tobacco and alcohol consumption. ${ }^{3}$

Several genetic alterations have been described in tumours from HNSCC patients, including non-random cytogenetic abnormalities, mutations or overexpression of the $\mathrm{H}$-ras, p53, and cyclin D genes, and alterations of the p $16^{\mathrm{INK} 4 \mathrm{~A}}$ gene. $^{4-8}$ Increased expression of epidermal growth factor receptor and mutations at several oncogenes have also been reported. ${ }^{910}$

Functional loss of tumour suppressor genes is one of the most common genetic alterations in human neoplasms. Defining chromosomal regions that harbour biologically important tumour suppressor genes may have practical implications for the diagnosis and management of these tumours. Cytogenetic studies have revealed that the short arm of chromosome 3 is often altered by chromosomal rearrangements and deletions in several cancer types, including HNSCC. ${ }^{4112}$ These data suggest the presence of one or more tumour suppressor genes located at $3 \mathrm{p}$, inactivation of which may contribute to HNSCC development. Three commonly deleted regions, mapped to $3 \mathrm{p} 24-$ ter, $3 \mathrm{p} 21.3$, and $3 \mathrm{p} 14$-cen, have recently been identified by analysis of allelic losses (loss of heterozygosity)..$^{13-15}$

Homozygous deletions are detected at a much lower frequency than heterozygous deletions and are usually smaller in size. Therefore homozygous deletions may be of considerable help in the localisation and identification of tumour suppressor genes. A $440 \mathrm{~kb}$ homozygous deletion mapped to the distal part of 3 p21 has been described in a small cell lung carcinoma cell line, where a tumour suppressor gene locus has been proposed. ${ }^{16}{ }^{17}$

Recently, the fragile histidine triad gene (FHIT) has been mapped to $3 \mathrm{p} 14.2$ and shown to span a renal carcinoma associated translocation breakpoint. ${ }^{18}$ Altered transcripts of FHIT were reported in about $80 \%$ of cases of small cell lung carcinoma. ${ }^{19}$ The $\beta$-catenin gene (CTNNB1) is located at chromosome region $3 \mathrm{p} 22-\mathrm{p} 21.3$, where loss of heterozygosity and homozygous deletion have been observed. ${ }^{20-22}$ The $\beta$-cat protein binds to E-cadherin and $\alpha$-catenin, thus being an essential component of the cell-cell adhesion complex, also critical for intracellular signalling pathways. ${ }^{23}$ Downregulation of $\beta$-catenin expression is associated with malignant transformation. ${ }^{25} \beta$-Catenin has recently been shown to act as an oncoprotein in melanoma 


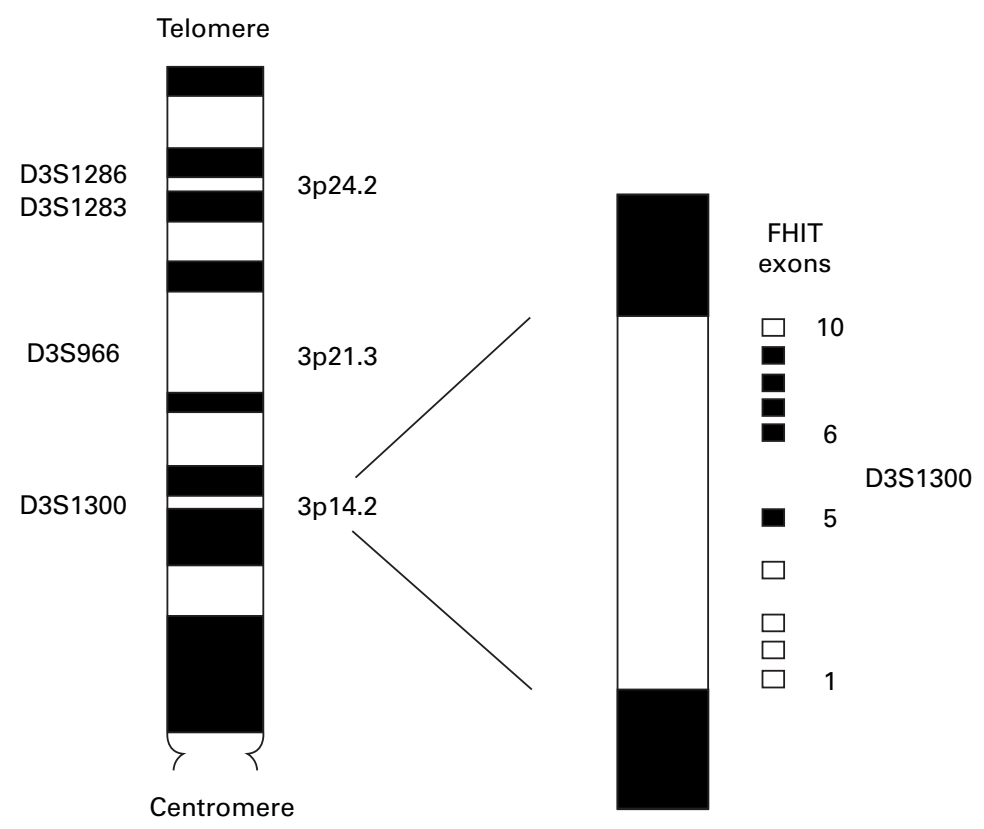

Figure 1 Chromosome $3 p$ map indicating the position of the microsatellite markers used (D3S1286, D3S1283, D3S966, D3S1300) and the FHIT gene (filled and empty boxes represent coding and non-coding exons, respectively).

and colon cancer cell lines. Small deletions and point mutations affecting Ser residues on its $\mathrm{NH}_{2}$-terminal domain have been described. ${ }^{26-28}$

In this report we investigated loss of heterozygosity at several $3 p$ regions in various HNSCC tumours. In addition, we searched for homozygous deletions and mutations at the FHIT and $\beta$-cat genes.

\section{Methods}

PATIENTS AND DNA EXTRACTION

Paired tumour and blood samples from 55 HNSCC patients were collected. The fresh tumour tissue was isolated by microdissection, and specimens containing more than $70 \%$ neoplastic cells were placed at $37^{\circ} \mathrm{C}$ for 24 hours in lysis solution containing sodium dodecyl sulphate (SDS) and proteinase $\mathrm{K}$. DNA was obtained after phenol-chloroform extraction and ethanol precipitation. ${ }^{29}$ DNA from leucocytes was obtained according to a previously described protocol. ${ }^{30}$

The 55 samples were from the pharynx (22), larynx (30), and floor of the mouth (3). Histologically, 27 were well differentiated, 17 were

Table 1 Oligonucleotide sequence of microsatellite markers used

\begin{tabular}{|c|c|c|c|c|}
\hline Marker & Region & Oligonucleotide sequence & Sizet & $T_{m}$ \\
\hline D3S1286 & $3 \mathrm{p} 24.2$ & $\begin{array}{l}\text { Fwd GCAGTGACTTCAGAGGGGC } \\
\text { Rvs ATTGACGGGGCTAGGGC }\end{array}$ & $120 \mathrm{bp}$ & $58^{\circ} \mathrm{C}$ \\
\hline D3S1283 & $3 \mathrm{p} 24.2$ & $\begin{array}{l}\text { Fwd GGCAGTACCACCTGTAGAAATG } \\
\text { Rvs GAGTAACAGAGGCATCGTGTAT }\end{array}$ & $120 \mathrm{bp}$ & $58^{\circ} \mathrm{C}$ \\
\hline D3S966 & $3 \mathrm{p} 21.3$ & $\begin{array}{l}\text { Fwd TACCTCCTCACTGTTTCATATTAG } \\
\text { Rvs CACATAGTATGTCTCGGCTAACAG }\end{array}$ & $120 \mathrm{bp}$ & $58^{\circ} \mathrm{C}$ \\
\hline D3S1300 & $3 \mathrm{p} 14.2$ & $\begin{array}{l}\text { Fwd AGCTCACATTCTAGTCAGCCT } \\
\text { Rvs GCCAATTCCCCAGATG }\end{array}$ & $220 \mathrm{bp}$ & $57^{\circ} \mathrm{C}$ \\
\hline Exon 5 FHIT & $3 \mathrm{p} 14.2$ & $\begin{array}{l}\text { Fwd TCAACTGTGAGGACATGTCG } \\
\text { Rvs TACCACAGGTTTCCTATTCA }\end{array}$ & $140 \mathrm{bp}$ & $58^{\circ} \mathrm{C}$ \\
\hline Exon 6 FHIT & $3 \mathrm{p} 14.2$ & $\begin{array}{l}\text { Fwd TACCCAAAGCCAGCAGCATG } \\
\text { Rvs TCACATCTGCCCTCCTGGTAAG }\end{array}$ & $280 \mathrm{bp}$ & $58^{\circ} \mathrm{C}$ \\
\hline Exon $3 \beta$ CAT & $3 \mathrm{p} 21.3$ & $\begin{array}{l}\text { Fwd ATTTGATGGAGTTGGACATGG } \\
\text { Rvs ACTTGTTCTTGAGTGAAGGACTG }\end{array}$ & $220 \mathrm{bp}$ & $65^{\circ} \mathrm{C}$ \\
\hline DD1 & $3 \mathrm{p} 21$ & $\begin{array}{l}\text { Fwd GGCTCTGCTTCCTGGTCCTTG } \\
\text { Rvs TTGGACAGCCTGTCTCCAGG }\end{array}$ & $230 \mathrm{bp}$ & $68^{\circ} \mathrm{C}$ \\
\hline
\end{tabular}

†For microsatellite markers, the size of the most frequent allele. moderately differentiated, and 11 were poorly differentiated tumours. With reference to tumour stage, two neoplasms were stage I, seven were stage II, 18 were stage III, and 28 were stage IV.

\section{MICROSATELLITE LOSS OF HETEROZYGOSITY} ANALYSIS

Microsatellite markers D3S1286 and D3S1283 (3p24.2), D3S966 (3p21.3), and D3S1300 (3p14.2) were analysed to determine the loss of heterozygosity at the short arm of chromosome 3. D3S1300 maps intragenic to the FHIT gene. Figure 1 represents the relative position of these markers. Primers were previously described and are summarised in table $1 .{ }^{13} 3132$ Polymerase chain reaction (PCR) was performed in a $15 \mu \mathrm{l}$ reaction volume containing 100 ng genomic DNA, 10 pmol of each primer, $200 \mu \mathrm{M}$ each of dATP, dGTP, and dTTP, $100 \mu \mathrm{M}$ dCTP, $2 \mathrm{mM} \mathrm{MgCl}, 0.10 \mu \mathrm{Ci}$ $\left[\alpha-{ }^{32} \mathrm{P}\right] \mathrm{dCTP} \quad(3000 \mathrm{Ci} / \mathrm{mmol}$, Amersham International, Amersham, Buckinghamshire, UK), $1 \times$ Taq buffer, and 0.5 units of Taq-DNA polymerase (Promega, Madison, Wisconsin, USA). Conditions consisted of an initial denaturing step of five minutes at $98^{\circ} \mathrm{C}$, followed by 25 cycles of 30 seconds at $98^{\circ} \mathrm{C}$, one minute at $58^{\circ} \mathrm{C}$, and 20 seconds at $72^{\circ} \mathrm{C}$, followed by a final extension of five minutes at $75^{\circ} \mathrm{C}$. Taq-DNA polymerase was added after the initial denaturing step. PCR products were mixed with one volume of denaturing loading buffer ( $95 \%$ formamide, $1 \%$ xylene cyanol), heated at $98^{\circ} \mathrm{C}$ for five minutes, and electrophoresed on a $6 \%$ denaturing polyacrilamide gel ( $45 \%$ urea, $5.7 \%$ acrylamide, and $0.3 \%$ bis-acrylamide). After electrophoresis the gels were vacuum dried and autoradiographed at $-80^{\circ} \mathrm{C}$ for $2-24$ hours.

After densitometric analysis of bands of the two matched samples, loss of heterozygosity was defined as a reduction of at least $75 \%$ in the signal of one allele in tumour DNA.

PCR AMPLIFICATION OF THE FHIT, $\beta$-CAT, AND DD1 LOCI

Genomic DNA from primary tumours was simultaneously amplified for exons 5 and 6 of the FHIT gene by multiplex PCR (the sets of primers for both loci were included in the PCR reaction mixture) under the same conditions as described for microsatellite analysis. A sequence mapped to $3 \mathrm{p} 21$, designated DD1, was also amplified, as well as exon 3 of the $\beta$-cat gene. PCR primers for these sequences were previously described and are summarised in table $1 .{ }^{33}{ }^{34}$ One microlitre of formamide was also added to the PCR reaction mixtures to improve PCR specificity. We also reduced the number of PCR cycles to 25 in order to minimise the masking effect of "contaminant" DNA from non-tumour cells. Electrophoresis was performed under the same conditions as described for microsatellite analysis.

SSCP ANALYSIS OF FHIT AND $\beta$-CAT

SSCP analysis was adapted from the original method of Orita et al. ${ }^{35}$ PCR amplification of FHIT exon 5 and $\beta$-cat exon 3 was performed 


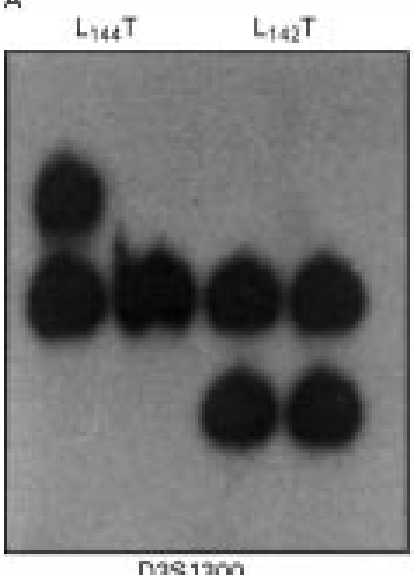

目

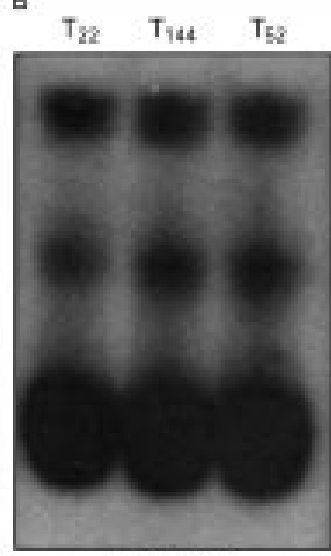

$\mathrm{EF}-\mathrm{FHIT}$
C
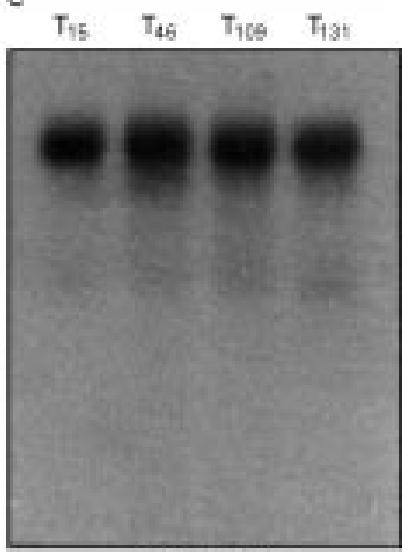

E3 - MCAT

Figure 2 (A) Positive and negative loss of heterozygosity (LOH) for marker D3S1300, intragenic to the FHIT gene. (B) PCR-SSCP analysis of exon 5 of FHIT gene. (C) PCR-SSCP analysis of exon 3 of $\beta$-cat gene.

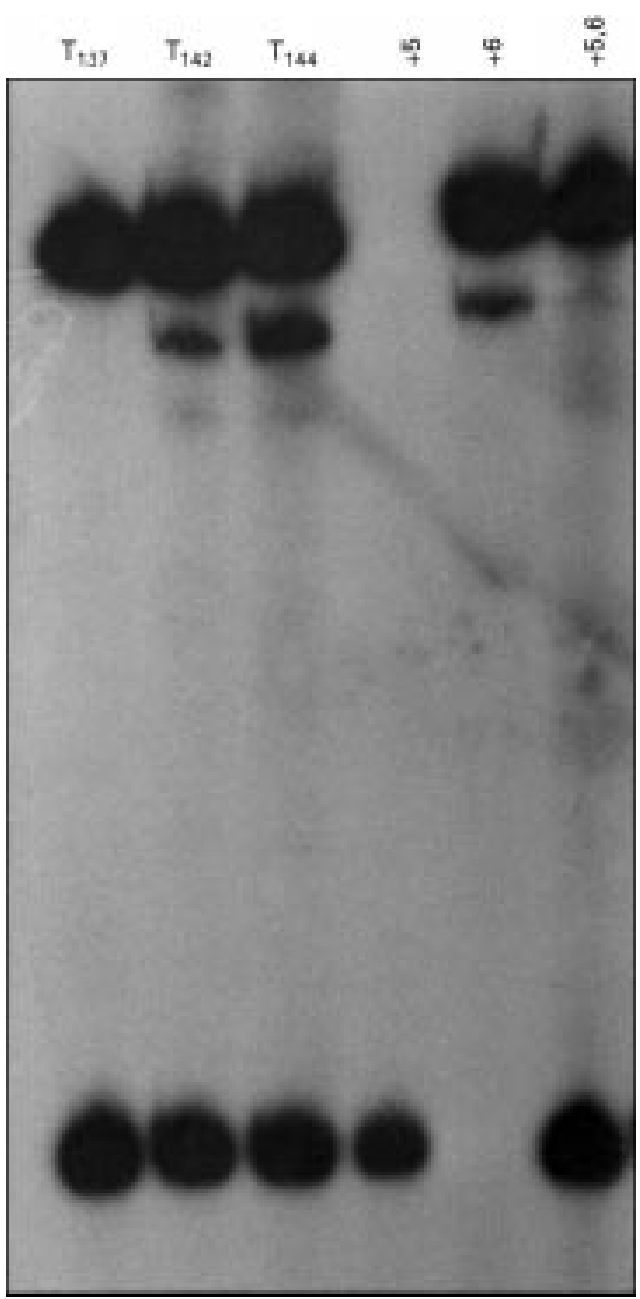

Figure 3 Multiplex polymerase chain reaction amplification of exons 5 and 6 of the FHIT gene.

as described for microsatellite analysis. Formamide denaturing loading buffer $(50 \mu \mathrm{l})$ was added to the reaction mixture and heated at $98^{\circ} \mathrm{C}$ for five minutes. Five microlitres were immediately loaded on a $6 \%$ polyacrilamide gel containing $10 \%$ glycerol. Electrophoresis was at $20 \mathrm{~W}$ for five hours at room temperature.

\section{Results}

To determine the relative incidence of loss of heterozygosity at chromosome 3 regions $3 \mathrm{p} 24.2$, 3p21.3, and $3 \mathrm{p} 14.2$, we compared the microsatellite patterns of DNA samples from 55 HNSCC with their normal tissue (lymphocyte) counterparts. Four microsatellite markers were used: D3S1283 and D3S1286 (3p24.2), D3S966 (3p21.3), and D3S1300 (3p14.2) (fig 1). The latter is intragenic to the FHIT gene and therefore loss of heterozygosity at this region represents the loss of one of the FHIT alleles. Fifty cases were informative for at least one of the markers, and loss of heterozygosity at $3 \mathrm{p}$ was found in $25(50 \%)$ of the patients (fig 2). The incidence of loss of heterozygosity for each marker was: $11 \%$ (5/45) for D3S1286; 37\% (15/40) for D3S1283; 63\% (19/30) for D3S966; and 32\% $(8 / 25)$ for D3S1300. No significant differences in the rate of $3 p$ loss of heterozygosity were found with respect to tumour stage.

None of the tumours showed homozygous deletion of the FHIT genes (exons 5 and 6) and the $\beta$-cat gene (exon 3) (fig 3). The DD1 locus was also amplified from the 55 tumours (data not shown). SSCP analysis of the FHIT (exon 5) and $\beta$-cat (exon 3 ) genes showed the same normal band pattern in every case, suggesting the absence of mutations at these sequences (fig 2 ).

\section{Discussion}

Loss of heterozygosity is one of the most common genetic alterations involved in cancer development and is associated with the presence of tumour suppressor genes. Regions of common loss of heterozygosity are found in HNSCC, including 9p21, 17p13, and $3 \mathrm{p}$. While tumour suppressor genes have been described as the main targets for $9 \mathrm{p} 21$ and $17 \mathrm{p} 13$ deletions ( $\mathrm{p} 16^{\mathrm{INK} 4 \mathrm{~A}}$ and $\mathrm{p} 53$, respectively), it is still not known which are the genes inactivated by $3 p$ deletions.

Three commonly deleted regions-mapped to $3 \mathrm{p} 24,3 \mathrm{p} 21.3$, and $3 \mathrm{p} 14$ - have been identified in HNSCC. ${ }^{13}$ Analysis with microsatellite markers D3S1283, D3S1286, D3S966, and D3S1300 allowed us to determine the inci- 
dence of allelic loss at the short arm of chromosome 3 in our patients. Fifty per cent of the cases showed loss of heterozygosity for at least one of the markers, a frequency similar to that reported by other investigators. ${ }^{1436} 37$ However, other reports described a higher loss of heterozygosity. ${ }^{13} 38$ These differences can partly be attributed to the different microsatellite markers used or to differences with respect to tumour grade and tumour stage. Loss of heterozygosity at $3 p$ was present in early stage tumours with a frequency that did not differ significantly from that of more advanced tumours. This suggests that $3 p$ loss of heterozygosity is an early event in HNSCC progression, as has been suggested by other investigators. ${ }^{39} 40$

Deletions at $3 p$ are the most common alterations in lung cancers, and three deleted regions have been reported for squamous cell lung carcinoma. ${ }^{15}$ This type of tumour shares histology and major aetiological factors, such as tobacco smoke, with HNSCC. This supports the hypothesis of a common oncogenic pathway for these two neoplasms and suggests the existence in $3 p$ of at least three tumour suppressor genes involved in the neoplasias of the aerodigestive tract. This is also supported by the similar pattern of $9 p$ and $17 p$ heterozygosity loss in both cancer types.

Exon specific PCR amplification showed that some lung cancer cell lines had intragenic homozygous deletions of exon 5 of the FHIT gene, mapped to $3 \mathrm{p} 14.2 .^{18}{ }^{33}$ This chromosomal region was identified as the most common fragile site in humans. ${ }^{41}$ Aberrant transcripts were reported in $80 \%$ of small cell lung carcinoma and $40 \%$ of non-small cell lung carcinoma. ${ }^{19}$ Exon 5 is the most consistently deleted of the FHIT exons in several types of cancer cell lines. ${ }^{42}$ Aberrant transcripts have also been reported in $60 \%$ of the HNSCC cell lines, with the deletion of exons 4 to 8 as the most common alteration. ${ }^{43}$ In order to assess whether the FHIT gene could be the target of 3 p14 deletions in primary HNSCC, we searched for homozygous deletions and exon 5 mutations at this gene. No tumour showed homozygous deletion, as assessed by multiplex PCR performed on a reduced number of cycles in order to minimise the effect of contaminant non-tumour DNA. This has allowed us to detect homozygous deletions in other genes. ${ }^{44}$ SSCP analysis suggested the absence of mutations. It is possible that mutations at the FHIT exon 5 are not detected by our SSCP analysis. However, this is not likely, since we have used this technique for the analysis of the p53 gene, and direct sequencing showed that we were able to detect most of the mutations. ${ }^{45}{ }^{46}$ Alternatively, the FHIT gene could be inactivated by mechanisms other than point mutation or homozygous deletion, such as transcription silencing by methylation, a mechanism involved in the inactivation of other tumour suppressor genes like $\mathrm{p} 16^{\mathrm{INK} 4 \mathrm{~A}} \cdot{ }^{47} \mathrm{We}$ also failed to find homozygous deletion at the DD1 locus, mapped to $3 \mathrm{p} 21$, a sequence homozygously deleted in a small cell lung carcinoma cell line. ${ }^{17}$
Finally, the human homologue of the bacterial DNA mismatch repair gene MutL (hMLH1) has been mapped to chromosome region $3 \mathrm{p} 21$ and is mutated in patients with hereditary non-polyposis colorectal cancer. ${ }^{48} 49$ The hMLH1 protein plays a role in the control of replication fidelity, and tumours with mutations at this gene are characterised by microsatellite instability as a result of mismatch repair deficiencies. We have not found any tumour showing this alteration, indicating that microsatellite instability is a rare event in the progression of HNSCC tumours and suggesting that hMLH1 is not the target of $3 p$ deletions in HNSCC.

This work was supported by grant FISS 96/1418 (EC). MVG is the recipient of a fellowship of the FICYT (Fundación para el fomento en Asturias de la Investigación Científica aplicada y la Tecnología).

1 Jacobs C, ed. Carcinomas of the head and neck: evaluation and management. London: Kluwer Academic Publishers, 1990. 2 Parkin DM, Laara E, Muir CS. Estimates of the worldwide frequency of 16 major cancers in 1980's. Int f Cancer 1988; 41:184-97.

3 Million RB, Cassisi NJ, Clark JR. Cancer of the head and neck. In: De Vita VT, Hellman S, Rosenberg SA, eds. Cancer: principles and practise of oncology. Philadelphia: JB Lippincott Co, 1989:488-590.

4 Heo DS, Synderman C, Gollin SM, et al. Biology, cytogenetics, and sensitivity to immunological effector cells of new head and neck squamous carcinoma lines. Cancer Res 1989;49:5167-75.

5 Saranath D, Chang SE, Bhoite LT, et al. High frequency of mutations in codons 12 and 61 of $\mathrm{H}$-ras oncogene in chewing tobacco related human oral carcinoma in India. $\mathrm{Br} F$ Cancer 1991;63:573-8.

6 Somers KD, Merrick A, Lopez ME, et al. Frequent p53 deletions in head and neck cancer. Cancer Res 1992;52: 5997-6000.

7 Wang X, Pavelic ZP, Li Y-Q, et al. Gene amplification and overexpression of the cyclin G1 gene in head and neck 256-9.

8 Sun Y, Hidesheim A, Lanier AEP, et al. No point mutations but decreased expression of the p16/MTS1 tumor suppressor gene in nasopharyngeal carcinoma. Oncogene 1995;10: 785-8.

9 Ishitoya J, Toriyama $\mathrm{M}$, Oguchi N, et al. Gene amplification nd overexpression of EGF receptor in squamous cell carcinomas of head and neck. Br F Cancer 1989;59:559-62.

10 Merrit WD, Wessler MC, Turk BF, et al. Oncogene amplification in squamous cell carcinoma of head and neck. Otolaryngol Head Neck Surg 1990;116:1394-8.

11 Cowan JM, Beckett MA, Ahmed-Swan S, et al. Cytogenetic evidence of the multistep origin of head and neck squamous cell carcinomas. F Natl Cancer Inst 1992;84:7937.

12 Sacks PG, Parnes SM, Gallick GE, et al. Establishment and characterization of two new squamous cell carcinoma cell lines derived from tumors of the head and neck. Cancer Res 1988;48:2858-66.

13 Maestro R, Gasparotto D, Vukosavljevic T, et al. Three discrete regions of deletion at $3 p$ in head and neck cancers. Cancer Res 1993;53:5775-9.

14 Wu CL, Sloan P, Read AP, et al. Deletion mapping on the short arm of chromosome 3 in squamous cell carcinoma of the oral cavity. Cancer Res 1994;54:6484-8.

15 Hibi K, Takahashi T, Yamakawa $\mathrm{K}$, et al. Three distinct regions involved in $3 \mathrm{p}$ deletion in human lung cancer. Oncogene 1992;7:445-9.

16 Killary AM, Wolf ME, Giambernardi TA, et al. Definition of a tumor suppressor locus within human chromosome 3p21-p22. Proc Natl Acad Sci USA 1992;89:10877-81.

17 Kok K, van der Berg A, Veldhuis PMJF, et al. A homozygous deletion in a small cell lung cancer cell line involving a 3 p21 region with a marked instability in yeast artificial chromoregion with a marked instability in yeas
somes. Cancer Res 1994;54:4183-7.

18 Ohta M, Inoue H, Cotticelli MG, et al. The FHIT gene, spanning the chromosome 3 p14.2 fragile site and renal carcinoma associated $\mathrm{t}(3 ; 8)$ breakpoint, is abnormal in digestive tract cancers. Cell 1996;84:587-97.

19 Sozzi G, Veronese ML, Negrini M, et al. The FHIT gene at 3 p14.2 is abnormal in lung cancer. Cell 1996;85:17-26.

20 Trent JM, Wiltshire R, Su L-K, et al. The gene for the APCbinding protein $\beta$-catenin (CTNNB1) maps to chromosome $3 \mathrm{p} 22$ region frequently altered in human malignancies. Cytogenet Cell Genet 1995;71:343-4.

21 Kraus C, Liehr T, Hülsken J, et al. Localization of the human $\beta$-catenin gene (CTNNB1) to $3 \mathrm{p} 21$ : a region implicated in tumor development. Genomics 1994;23:2724. 
22 van Hengel J, Nollet F, Berx G, et al. Assignment of the human $\beta$-catenin gene (CTNNB1) to $3 \mathrm{p} 22-\mathrm{p} 21.3$ by fluorescen

23 Oyama T, Kanai Y, Ochiai A, et al. A truncated beta-catenin disrupts the interaction between E-cadherin and alphacatenin: a cause of loss of intercellular adhesiveness in human cancer cell lines. Cancer Res 1994;54:6282-7.

24 Jou T-S, Stewart DB, Stappert J, et al. Genetic and biochemical dissection of protein linkages in the cadherincatenin complex. Proc Natl Acad Sci USA 1995;92:506771.

25 Takayama T, Shiozadi H, Shibamoto S, et al. $\beta$-Catenin expression in human cancers. Am f Pathol 1996;148:39-46.

26 Korinek V, Barker N, Morin PJ, et al. Constitutive transcriptional activation by a $\beta$-catenin-Tcf complex in $\mathrm{APC}^{-/}$colon carcinoma. Science 1997;275:1784-6.

27 Morin PJ, Sparks AB, Korinek V, et al. Activation of $\beta$-catenin-Tcf signaling in colon cancer by mutations in $\beta$-catenin-Tcf signaling in colon cancer by

28 Rubinfeld B, Robbins P, El-Gamil M, et al. Stabilization of $\beta$-catenin by genetic defects in melanoma cell lines. Science $\beta$-catenin by genetic

29 Sambrook J, Fritsch EF, Maniatis T. Molecular cloning: a laboratory manual. Cold Spring Harbor, NY: Cold Spring Harbor Laboratory, 1989

30 Miller SA, Dykes DD, Polesky HF. A simple salting out procedure for extracting DNA from human nucleated cells. Nucleic Acids Res 1988;16:1215.

31 The 1993-94 Généthon human genetic linkage map. Nature Genet 1994;7:263.

32 Naylor SL, Buys CHCM, Carritt B. Report on the fourth international workshop on human chromosome 3 mapping 1993. Cytogenet Cell Genet 1994;65:1-50.

33 Yanagisawa $\mathrm{K}$, Kondo $\mathrm{M}$, Osada $\mathrm{H}$, et al. Molecular analysis of the FHIT gene at 3p14.2 in lung cancer cell lines. Cancer Res 1996;56:5579-82.

34 Gemma A, Hagiwara K, Ke Y, et al. FHIT mutations in human primary gastric cancer. Cancer Res 1997;57:1435-7.

35 Orita M, Suzuki Y, Sekiya T, et al. Rapid and sensitive detection of point mutations and DNA polymorphisms using

36 El-Naggar AK, Hurr K, Batsakis JG, et al. Sequential loss of heterozygosity at microsatellite motifs in preinvasive and invasive head and neck squamous carcinoma. Cancer Res 1995;55:2656-9.
37 Bockmühl U, Schwenel A, Dietel M, et al. Distinct patterns of chromosomal alterations in high- and low-grade head and neck squamous cell carcinomas. Cancer Res 1996;56: 5325-9.

38 Scholnick SB, Sun PC, Shaw ME, et al. Frequent loss of heterozygosity for $\mathrm{Rb}, \mathrm{TP} 53$ and chromosome arm $3 \mathrm{p}$, but not NME1 in squamous cell carcinomas of the supraglottic larynx. Cancer 1994;73:2472-80.

39 Nawroz H, van der Riet P, Hruban RH, et al. Allelotype of head and neck squamous cell carcinoma. Cancer Res 1994; $54: 1152-5$.

40 Califano J, van der Riet P, Westra W, et al. A genetic progression model for head and neck cancer: implications for field cancerization. Cancer Res 1996;56:2488-92.

41 Smeets DFCM, Scheres JMJC, Hustinx TWJ. The most common fragile site in man is 3p14. Hum Genet 1986;72:215-20.

42 Druck T, Hadaczek P, Fu T-B, et al. Structure and expression of the human FHIT gene in normal and tumor cells. Cancer Res 1997;57:504-12.

43 Virgilio L, Shuster M, Gollin SM, et al. FHIT gene alterations in head and neck squamous cell carcinomas. Proc Natl Acad Sci USA 1996;93:9770-5.

44 González MV, Pello MF, López-Larrea C, et al. Deletion and methylation of the tumor suppressor gene p16/ CDKN2 in primary head and neck squamous cell CDKN2 in primary head and neck

45 González MV, Pello MF, López-Larrea C, et al. Loss of heterozygosity and mutation analysis of the p16 (9p21) and p53 (17p13) genes in squamous cell carcinoma of the head and neck. Clin Cancer Res 1994;1:1043-9.

46 González MV, Artímez ML, Rodrigo L, et al. Mutation analysis of the p53, APC and p16 genes in the Barrett's oesophagus, dysplasia and adenocarcinoma. 7 Clin Pathol 1997;50:212-7.

47 González-Zulueta M, Bender CM, Yang AS, et al. Methylation of the 5' $\mathrm{CpG}$ island of the p16/CDKN2 tumour suppressor gene in normal and transformed human tissues correlates with gene silencing Cancer Res 1995;5:4531-5.

48 Bronner CE, Baker SM, Morrison PT, et al. Mutation in the DNA mismatch repair gene homologue hMLH1 is associated with hereditary non-polyposis colon cancer. Nature 1994;368:258-61.

49 Papadopoulos N, Nicolaides NC, Wei Y-F, et al. Mutation of mutL homolog in hereditary colon cancer. Science 1994; 263:1625-9. 